\title{
TRACE ELEMENT BIOACCUMULATION IN THE EDIBLE MILK SNAIL (OTALA LACTEA) AND CABRILLA (OTALA PUNCTATA) IN MARRAKECH, MOROCCO
}

\author{
SebBan, H. ${ }^{*}-$ Ait Belcaid, H. ${ }^{1}-$ El Alaoui El Fels, A. ${ }^{2}-$ BouriQi, A. ${ }^{1}-$ PineaU, A. ${ }^{3}-$ \\ SEDKI, A. ${ }^{1}$ \\ ${ }^{1}$ Department of Biology, Faculty of Science Semlalia, Cadi Ayyad University, Marrakech, \\ Morocco \\ ${ }^{2}$ Department of Biology, Faculty of Science and Techniques, Cadi Ayyad University, \\ Marrakech, Morocco \\ ${ }^{3}$ Department of Clinical Pharmacology, University Hospital of Nantes, Nantes, France \\ *Corresponding author \\ e-mail: hajarsebban@gmail.com \\ (Received $13^{\text {th }}$ Oct 2021; accepted $22^{\text {nd }}$ Dec 2021)
}

\begin{abstract}
Morocco is the first land snail exporter in the world and the majority of snail production consists of individuals collected from nature. These gastropods are known to accumulate high levels of trace metals in their tissues hence the main objective of this study. We aimed firstly to investigate the bioaccumulation efficiency of $\mathrm{Pb}, \mathrm{Cd}, \mathrm{Zn}, \mathrm{Cu}$ and $\mathrm{Ca}$ in Otala spp. snails, the most commonly widespread and the most consumed species in the Marrakech region, and then evaluate the potential risk on human health. Soil, foot, viscera and shell of adult snails were picked from six sampling stations in Al Haouz plain and analysed by ICP-MS. Results showed that the investigated snails accumulated all the examined elements with significant variations among the different tissues. The Principal Component and Bioaccumulation Factor analyses demonstrated that Otala spp. are macroconcentrators for $\mathrm{Cd}$ and microconcentrators for $\mathrm{Pb}$. Furthermore, their shell accumulated more $\mathrm{Ca}$, foot accumulated more $\mathrm{Cu}$ and viscera accumulated more $\mathrm{Zn}, \mathrm{Cd}$ and $\mathrm{Pb}$. In addition, the detected concentrations of toxic metals $(\mathrm{Pb}$ and $\mathrm{Cd}$ ) were higher than the maximum admissible limits according to the European regulation except for $\mathrm{Pb}$ in the reference station. In conclusion, Otala spp. snails in our region can be used as bioindicators of trace element bioavailability and their consumption must be limited to avoid any possible intoxications.
\end{abstract}

Keywords: terrestrial invertebrates, bioindicators, metallic pollution, ICP-MS, health risk assessment

\section{Introduction}

During the last few decades, the environment and its compartments have been severely degraded due to the increasing anthropogenic activities. Most of these activities, especially industrial and agricultural ones, are responsible for the most trace element contaminations occurring in soil, air, water and organisms. Thus, the nondegradable state and the detrimental effect of these trace elements on the physiological functions of living organisms (Luczynska et al., 2018; Parolini et al., 2021) are becoming a big concern around the world.

To detect the deposition, accumulation and distribution of metallic pollution, direct measurements with physical and chemical methods can be used but require high expenditure and expertise, take more time and can release additional waste to the environment. In this context, Biomonitoring becomes an alternative to provide real and momentary information about the biological changes deriving from environmental exposure to chemicals. In fact, a biomonitor is an organism giving information on the 
quality of its habitat; it is usually characterized by its sedentary lifestyle, wide distribution and ease of identification and collection (Parmar et al., 2016; Jahan and Strezov, 2019). Furthermore, several studies worldwide have shown the success of this approach to evaluate soil quality with the aid of soil invertebrates (Minodora, 2017; Chrzan, 2017) such as land snails (De Roma, 2017), isopods (Ghemari et al., 2017) and earthworms (Wang et al., 2018), air quality with plant leaves, pollen and barks (Ejidike and Onianwa, 2015; Shahid et al., 2016; Orcid and Orcid, 2019) and water quality with algae and aquatic mollusks (Pankova et al., 2015; Manev et al., 2020).

In the soil, trace elements are absorbed by microorganisms or assimilated by root systems (Munees, 2019; Caracciolo and Terenzi, 2021). It is for this reason that the use of sentinel terrestrial organisms to monitor the soil quality is very practical, due to their distribution, easy sampling, tolerance to stress and their ability to accumulate various pollutants (Anim et al., 2011; Mohammadein et al., 2013). Land snails are among the best bioindicators of terrestrial pollution because of their direct contact with several elements of their biotope (Gomot De Vaufleury and Pihan, 2000; Shotuyo et al., 2016; Ugbaja et al., 2020). These macro-invertebrates are ideally located at the interface between soil, plants and air; they eat soil and vegetation, and breathe through a big pneumostoma which can transport some particles to the pallial cavity. Moreover, the important place occupied by these gastropods in the food chain of terrestrial ecosystems may threaten organisms at higher trophic levels, such as humans and some snail predators.

For a long time, land snails, commonly named "Bebouch" or "Ghlala" have been a traditional dish in Moroccan cuisine and still highly appreciated by local consumers and tourists. They are considered a valuable source of nutrients, rich in proteins of high biological value and low in saturated fat. They are also rich in certain minerals and trace elements such as Calcium, Magnesium, Phosphorus, Iron, Copper and vitamins (B6, B12 and C) (Gomot, 1998). Furthermore, Morocco remains the top snail exporter in the world (15.7\% of world exports) followed by Romania (7.42\%), Turkey (5.94\%), France (5.93\%) and Indonesia (5.71\%) (Indexbox, 2019). The majority of the Moroccan production comes from snails gathered in the wild which develop naturally without any human intervention. These snails are found in abundance in limestone areas, in forests, gardens, fields and other localities that may be contaminated (pesticides, molluscicides, fertilizers, wastewater...). In these environments, snails can assimilate contaminants through ingestion, respiratory or skin tract and can sometimes become invalid for consumption.

The aim of this study is to document and evaluate some trace element contents $(\mathrm{Pb}$, $\mathrm{Cd}, \mathrm{Zn}, \mathrm{Cu}$ and $\mathrm{Ca}$ ) in soils, foot, viscera and shell of Otala lactea and Otala punctata snails, the most consumed snails in the Marrakech region and the most exported species in the international market. The purpose is firstly to assess the potential of these land snails as biomonitors of terrestrial environment quality of five farms with agricultural activities, then to evaluate their safety as a food resource based on the levels of accumulated toxic elements $(\mathrm{Pb}$ and $\mathrm{Cd}$ ) especially in foot, the most edible part of snails.

\section{Materials and methods}

All experiments were ethically conducted in conformity to principles and guidelines of animal welfare in scientific research (APA, 2018). 


\section{Study area description}

The study was carried out in six regions in Al Haouz plain (Marrakech, Morocco). Al Haouz plain is located in the Tensift basin, on the Northern slope of the High Atlas. It covers an area of approximately $6000 \mathrm{~km}^{2}$ with the city of Marrakech as the capital. The sampling locations belong to Four Provinces, namely Marrakech Province, Al Haouz Province, Rehamna Province and El-Kelaa des Sraghnas Province (Fig. 1).

The sampling technique was similar to that of the commercial snail collectors who respect specific collecting places and times. Generally, snails are collected from private farms or from public fields known for their limestone-rich soil and high humidity such as cool mountain areas and steamy forests. Furthermore, it is necessary to collect only adult snails obligatorily out of rest periods (only during spring and autumn in our region).

Following the same process, our soil and Otala spp. snail samples were collected in April 2019 from six different sampling stations (Table 1). Loudaya, Ourika and Laâtamna stations are big farms with commercial production. Contrariwise, Tahannaout and Sâada stations are small farms with personal production. El Argoub station is an open area without any agricultural production and was considered as a reference site during this study.

The choice of the study areas was based on the investigation of the High Commission for Planning of Morocco (HCP) showing that there is an intensive use of fertilizers and pesticides in the Marrakech region contributing directly to soil contamination. This region uses nearly 120,000 tons of fertilizers annually, i.e. $16 \%$ of the national consumption of these products. Otherwise, the excessive use of these elements also causes pollution of water resources (between $30 \%$ and $39 \%$ of groundwater resources are of poor quality) (HCP, 2018).

Loudaya, Ourika and Laâtamna stations are more exposed to these possible contamination sources due to the intensive agricultural activities intended for the large market.

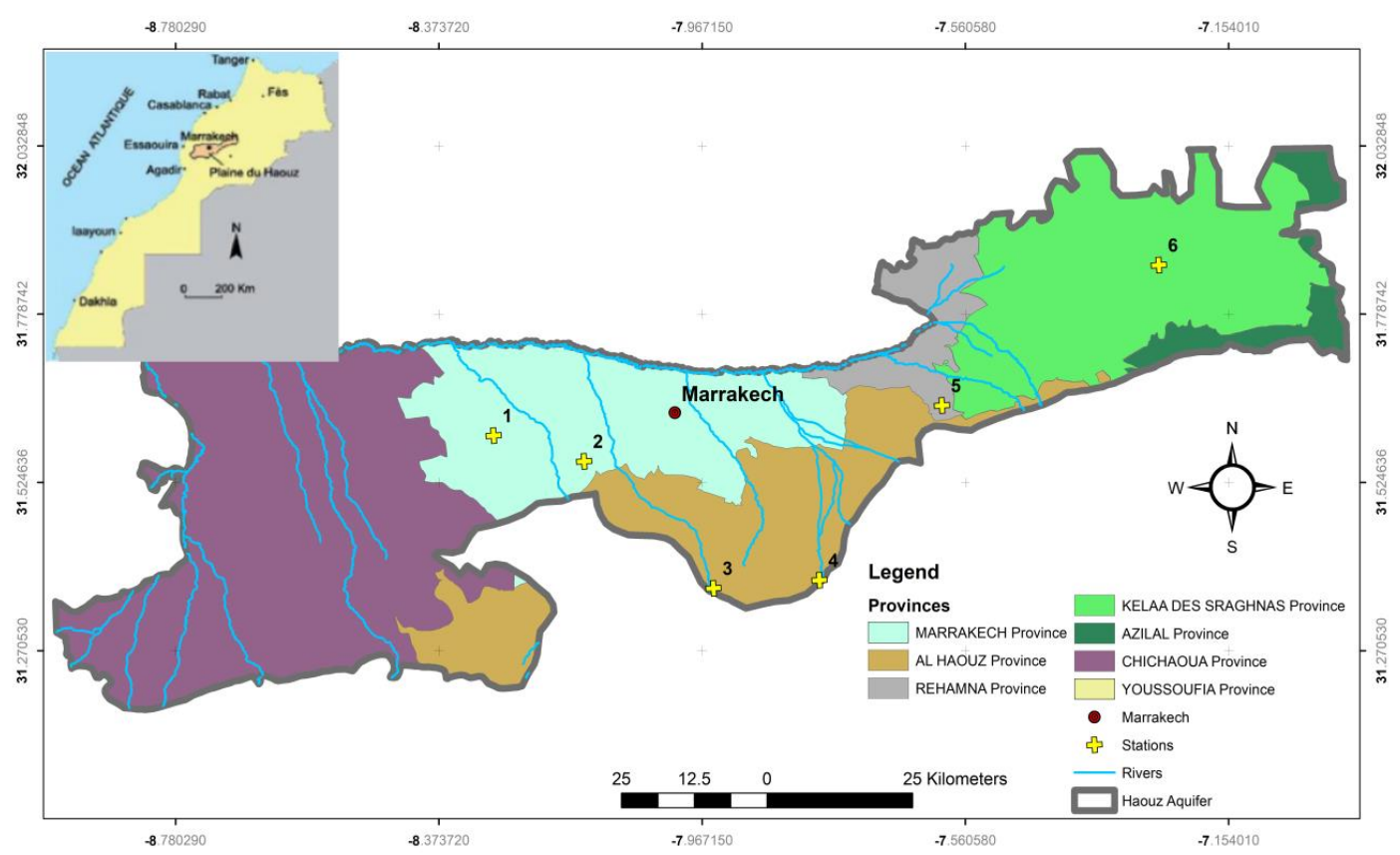

Figure 1. Map showing the geographical distribution of soil and snail sampling stations 


\section{Snail sampling}

A minimum of 30 - 40 adult snail specimens were collected at each sampling site in order to obtain enough biomass for different identification and chemical analyses. The choice of plots was random and depended in particular on the presence of a sufficient number of individuals. Subsequently, all the collected individuals were subjected to a descriptive study measuring the following parameters: shell height and shell width with a digital vernier caliper (Selecta 5900603) and snail weight with precision analytical balance (Radwag AS 220.R2) (Table 1).

Table 1. Soil and snail sampling stations and snails description

\begin{tabular}{|c|c|c|c|c|c|c|}
\hline $\begin{array}{l}\text { Station } \\
\text { code }\end{array}$ & Station & Geographic coordinates & Altitude & $\begin{array}{c}\text { Snail wet } \\
\text { weight }(g)\end{array}$ & $\begin{array}{c}\text { Shell height } \\
(\mathrm{mm})\end{array}$ & $\begin{array}{c}\text { Shell width } \\
(\mathbf{m m})\end{array}$ \\
\hline $\mathrm{S} 1$ & & $31^{\circ} 35^{\prime} 34.8^{\prime \prime} \mathrm{N}, 8^{\circ} 17^{\prime} 15.1^{\prime \prime} \mathrm{W}$ & & $4.8 \pm 0.2$ & $15.4 \pm 0.6$ & $29.6 \pm 1.0$ \\
\hline $\mathrm{S} 2$ & Sâada & $31^{\circ} 33^{\prime} 15.3^{\prime \prime} \mathrm{N}, 8^{\circ} 08^{\prime} 52.1^{\prime \prime} \mathrm{W}$ & $451 \mathrm{~m}$ & $4.7 \pm 0.1$ & $13.8 \pm 0.3$ & $26.4 \pm 0.4$ \\
\hline S3 & Tahannaout & $31^{\circ} 21^{\prime} 44.9 " \mathrm{~N}, 7^{\circ} 56^{\prime} 52.6^{\prime \prime} \mathrm{W}$ & $896 \mathrm{~m}$ & $6.7 \pm 0.3$ & $16.9 \pm 0.5$ & $30.7 \pm 0.5$ \\
\hline S4 & Ourika & $31^{\circ} 22^{\prime} 28.7^{\prime \prime} \mathrm{N}, 7^{\circ} 47^{\prime} 04.3 ” \mathrm{~W}$ & $855 \mathrm{~m}$ & $5.3 \pm 0.3$ & $16.3 \pm 0.7$ & $30.1 \pm 1.6$ \\
\hline S5 & El Argoub & $31^{\circ} 38^{\prime} 18.7^{\prime \prime} \mathrm{N}, 7^{\circ} 35^{\prime} 42.4^{\prime \prime} \mathrm{W}$ & $593 \mathrm{~m}$ & $6.4 \pm 0.4$ & $15.5 \pm 0.5$ & $30.0 \pm 0.6$ \\
\hline S6 & Laâtamna & $31^{\circ} 51^{\prime} 02.1^{\prime \prime} \mathrm{N}, 7^{\circ} 15^{\prime} 36.3 ” \mathrm{~W}$ & $615 \mathrm{~m}$ & $5.6 \pm 0.3$ & $17.7 \pm 0.8$ & $29.4 \pm 0.7$ \\
\hline
\end{tabular}

\section{Snail species}

Otala spp. snails are chosen for this investigation because they are the most widespread and the most common edible species in Marrakech and regions. They are also relatively abundant and well spatially distributed over the study areas. In addition, the trace element contents and the accumulative potential of these species have never been studied. There are two popular species that have been used as food since ancient times, namely Otala lactea and Otala punctata (Müller, 1774). They are very similar morphologically and sometimes require a dissection for a correct identification.

Otala lactea (Helicidae family) is a land snail generally native to the Mediterranean. It is characterized by a solid shell with a whitish, yellow or brown color (influences by habitat) with 4 to 5 darker bands. Likewise, Otala punctata (Helicidae family) is native to the Iberian Peninsula, southern France and the Maghreb region of North Africa. (Herbert, 2010). The shell of this species is patterned of dark and light, brownish, spiral bands overlain with numerous tiny white spots. O. lactea is distinguished from $O$. punctata by the color of the aperture and peristome, which is very dark or black in the first and light brown or whitish in the second. Otala lactea occurs sympatrically with Otala punctata and both species exhibit similar life cycle patterns. (Robinson et al., 1998).

\section{Snails and soil preparation}

\section{Soil preparation}

For each selected station, three soil samples were collected randomly from $0-5 \mathrm{~cm}$ of sediments with a hand grab sampler. Then, they are homogenized, kept in zip-locked plastic bags, labeled and transported to the laboratory for further treatments and analyses. Once in the laboratory, they are air-dried for 7-10 days at ambient temperature, sieved by a $2 \mathrm{~mm}$ sieve and weighed for the next analysis step. 


\section{Snail dissection and tissue preparation}

Collected snails were transported to the laboratory in coolers, then, purged by starvation for $48 \mathrm{~h}$ to remove unabsorbed food and feces from their digestive tract. Afterwards, they are washed three times with deionized water to remove impurities and to avoid possible interference between the metals present in the ingested food and the real amounts of metals accumulated in the snail tissues.

As already mentioned, this study focused on $O$. lactea and $O$. punctata species. For this reason, the individuals are firstly sorted based on their morphology, and then a group of 5 individuals per location was a subject of a reproductive system dissection, the most important indicator for classifying snails, to confirm the preliminary selection. Results of this dissection are presented in Figure 2.

The other groups of selected snails were sacrificed by freezing at $-20{ }^{\circ} \mathrm{C}$. The next step was to remove the whole soft tissue from the shell and separate the viscera from the foot. Afterwards, shells, feet and viscera were oven-dried separately at $60{ }^{\circ} \mathrm{C}$ until they reached a constant dry weight, then grinded to a powder by using a mortar made of steel guaranteed "without Trace Metallic Elements".

\section{The control snail rearing}

The snails used for the control sample were obtained by snail rearing in standard conditions in an aboveground system at the laboratory. For that, adult Otala spp. snails, already gathered and identified, were placed in a refrigerator at $6-7^{\circ} \mathrm{C}$ for 3 months, to trigger the hibernation process and promote the chances of mating after awakening. They are then put in a regulated room with a photoperiod of $18 \mathrm{~h}$ of light per day, a temperature of $22{ }^{\circ} \mathrm{C}$ and a relative humidity of about $85 \%$.

In those conditions, individuals mating, nest digging and eggs lying take about 30 days. After the eggs hatch, the baby snails are transferred to plastic boxes and fed, for a period ranging from 3 to 4 months, with a composed food containing a source of calcium, proteins and energy. Adult individuals went through the same preparation steps already mentioned for the other samples.

\section{Chemical preparation}

\section{Soil analysis}

Soil samples were chemically analyzed for detection of trace elements $(\mathrm{Pb}, \mathrm{Cd}, \mathrm{Zn}$, $\mathrm{Cu}, \mathrm{Ca})$ using the digestion technique by aqua regia $\left(\mathrm{HNO}_{3}+\mathrm{HCl}\right)$. This digestion consisted of soaking $250 \mathrm{mg}$ of each soil sample in $3 \mathrm{~mL}$ of ultrapure Nitric acid $65 \%$ for $2 \mathrm{~h}$, and then adding $6 \mathrm{~mL}$ of Chloric acid 34\%. The digestion of all samples was carried out in pressure vessels using a microwave (Multiwave GO) according to the following program:

- 10 min at $80^{\circ} \mathrm{C}$

- 15 min at $80^{\circ} \mathrm{C}$

- 5 min at $150{ }^{\circ} \mathrm{C}$

- and finally 35 min $150^{\circ} \mathrm{C}$.

After the end of this process, the samples were cooled, centrifuged for $10 \mathrm{~min}$ and filtered. Afterwards, $1 \mathrm{~mL}$ of each digested sample was diluted to $10 \mathrm{~mL}$ with ultrapure water and stored at $4{ }^{\circ} \mathrm{C}$ prior to analysis. 


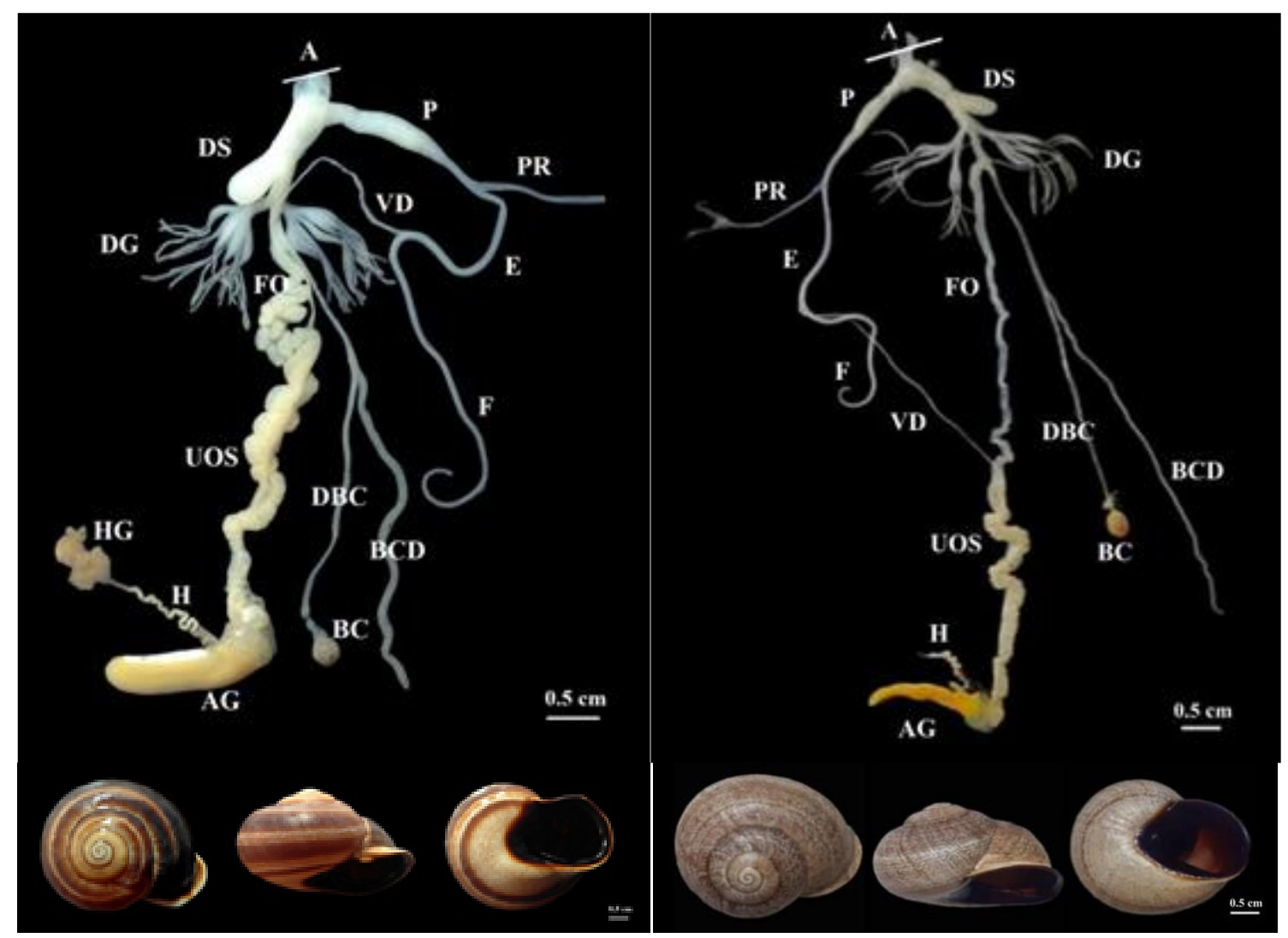

Figure 2. Shell and reproductive system dissection of Otala punctata $(A)$ and Otala lactea $(B)$ snails. Legend: A: atrium; AG: albumen gland; BC: bursa copulatrix; $B C D$ : diverticulum of the bursa copulatrix; DBC: duct of the bursa copulatrix; DG: digitiform glands; DS: dart sac; E: epiphallus; F: flagellum; FO: free oviduct; $H$ : hermaphroditic duct; $H G$ : Hermaphroditic glandula; P: penis; PR: penial retractor muscle; UOS: uterine ovispermiduct; VD: vas deferens

\section{Snail analysis}

At the same time of soil, snail analysis was carried out as follows: $100 \mathrm{mg}$ of each sample of shells, feet and viscera was digested separately in $1 \mathrm{~mL}$ of Nitric acid $65 \%$ for $24 \mathrm{~h}$. Subsequently, the mineralization process was completed on a hot plate at $80{ }^{\circ} \mathrm{C}$ for $1 \mathrm{~h}$. One hour of digestion was sufficient to completely digest the samples without leaving any traces or debris. Then, $1 \mathrm{~mL}$ of each concentrate was diluted with $1 \mathrm{~mL}$ of ultrapure water. The dilution factor was chosen based on the results of preliminary assays.

Trace elements concentrations $(\mathrm{Pb}, \mathrm{Cd}, \mathrm{Zn}, \mathrm{Cu})$ in soil, shells, feet and viscera samples were determined by inductively coupled plasma mass spectrometry (ICP-MS (Perkin Elmer)). Two standard reference materials were used to validate the method, NIST 1643 and NIST 1640 for snail samples and NIST 1643 with MESS-2 for soil samples.

Afterwards, Calcium contents were measured by a Flame Photometer (Sherwood 360). The stock solution of feet, viscera and soil was diluted 100-fold; the stock solution of shells was diluted 1000-fold. These dilutions were necessary in order to obtain more credible results. 


\section{Statistical analysis}

Mean and standard deviation (SD) were calculated for all variables. The soil mean values and snail mean values were compared by unpaired student's t-test for statistically significant differences. Differences were considered significant when $p \leq 0.05$. In order to estimate the proportion in which metal occurs in the snail tissues and in associated soil, the bioaccumulation factor (BAF) was calculated according to the formula: Concentration of the element in snail tissue / Concentration of the same element in soil. Then, to evaluate the metals' concentrations in the different snails' parts (Foot, viscera and shell), Principal Components Analysis (PCA) was used. All the statistical analyses were performed using R-studio.

\section{Results}

\section{Trace element concentrations in soils of sampling locations}

Levels of investigated elements $(\mathrm{Pb}, \mathrm{Cd}, \mathrm{Zn}, \mathrm{Cu}$ and $\mathrm{Ca}(\mu \mathrm{g} / \mathrm{g}$, dry weight)) in soils of the different studied stations are presented in Figure 3. The results showed $\mathrm{Cd}$ presented the lowest concentrations, followed by $\mathrm{Pb}, \mathrm{Cu}, \mathrm{Zn}$ then $\mathrm{Ca}$.

The collected data showed also that the studied elements were ranged between 0.16$0.38,13.73-22.89,33.57-61.06,104.77-155.33$, and 1406.25-27000 $\mu \mathrm{g} / \mathrm{g}$ for $\mathrm{Cd}, \mathrm{Pb}$, $\mathrm{Cu}, \mathrm{Zn}$ and $\mathrm{Ca}$ respectively. Furthermore, the reference station registered the lowest levels of toxic elements $(\mathrm{Pb}$ and $\mathrm{Cd})$ while Loudaya station registered the highest concentration of these metals.

In comparison with the reference station, it has been observed that there was a statistically significant difference $(\mathrm{p} \leq 0.05)$ between the reference station and all the sampling stations for $\mathrm{Cd}$ and $\mathrm{Ca}$ concentrations in soil. However, the difference in $\mathrm{Pb}$ concentrations was statistically significant only between the reference station and Loudaya, Tahannaout and Ourika. The Zn concentrations in the soil of El Argoub were significantly lower than those in Loudaya, Tahannaout and Ourika soils. Furthermore, there was no significant difference in $\mathrm{Cu}$ concentrations between the reference station and Ourika $(\mathrm{p}=0,170)$.

\section{Trace element concentrations in Otala spp. snails}

The levels of the examined elements $\mathrm{Pb}, \mathrm{Cd}, \mathrm{Zn}, \mathrm{Cu}$, and $\mathrm{Ca}(\mu \mathrm{g} / \mathrm{g}$, dry weight) in different parts of Otala spp. snails collected from the six sampling stations are given in Table 2. In fact, all the studied trace elements were detected in our sampled snails.

The obtained results from the analysis of these snail samples were firstly compared for the whole snail body (soft tissue and shell) in different sampling stations. It was found that at each locality the concentrations fluctuate in the following order: $\mathrm{Pb}<\mathrm{Cd}<\mathrm{Zn}<\mathrm{Cu}<\mathrm{Ca}$. The results also revealed that the recorded average of nonessential element concentrations vary between $1.41 \mu \mathrm{g} / \mathrm{g}$ and $6.63 \mu \mathrm{g} / \mathrm{g}$ for $\mathrm{Pb}$ and between $8.33 \mu \mathrm{g} / \mathrm{g}$ and $15.48 \mu \mathrm{g} / \mathrm{g}$ for $\mathrm{Cd}$ and that $\mathrm{Cd}$ is more concentrated than $\mathrm{Pb}$. On the other hand, the recorded essential element concentrations are within $233.28 \mu \mathrm{g} / \mathrm{g}$ and $363.67 \mu \mathrm{g} / \mathrm{g}, 280.23 \mu \mathrm{g} / \mathrm{g}$ and $572.06 \mu \mathrm{g} / \mathrm{g}$ and $388.08 .10^{3}$ and $442.10^{3} \mu \mathrm{g} / \mathrm{g} \mu \mathrm{g} / \mathrm{g}$ for Zinc, Copper and Calcium respectively.

The comparison between the control animals and all the other samples shows that the $\mathrm{Pb}, \mathrm{Cd}$ and $\mathrm{Cu}$ contents in control snails were significantly lower than those of the examined ones (including the reference station). $\mathrm{Zn}$ contents were significantly different 
for only Tahannaout and Ourika stations. In contrast, there was no significant difference in Ca concentrations ( $\mathrm{p}>0.05)$.

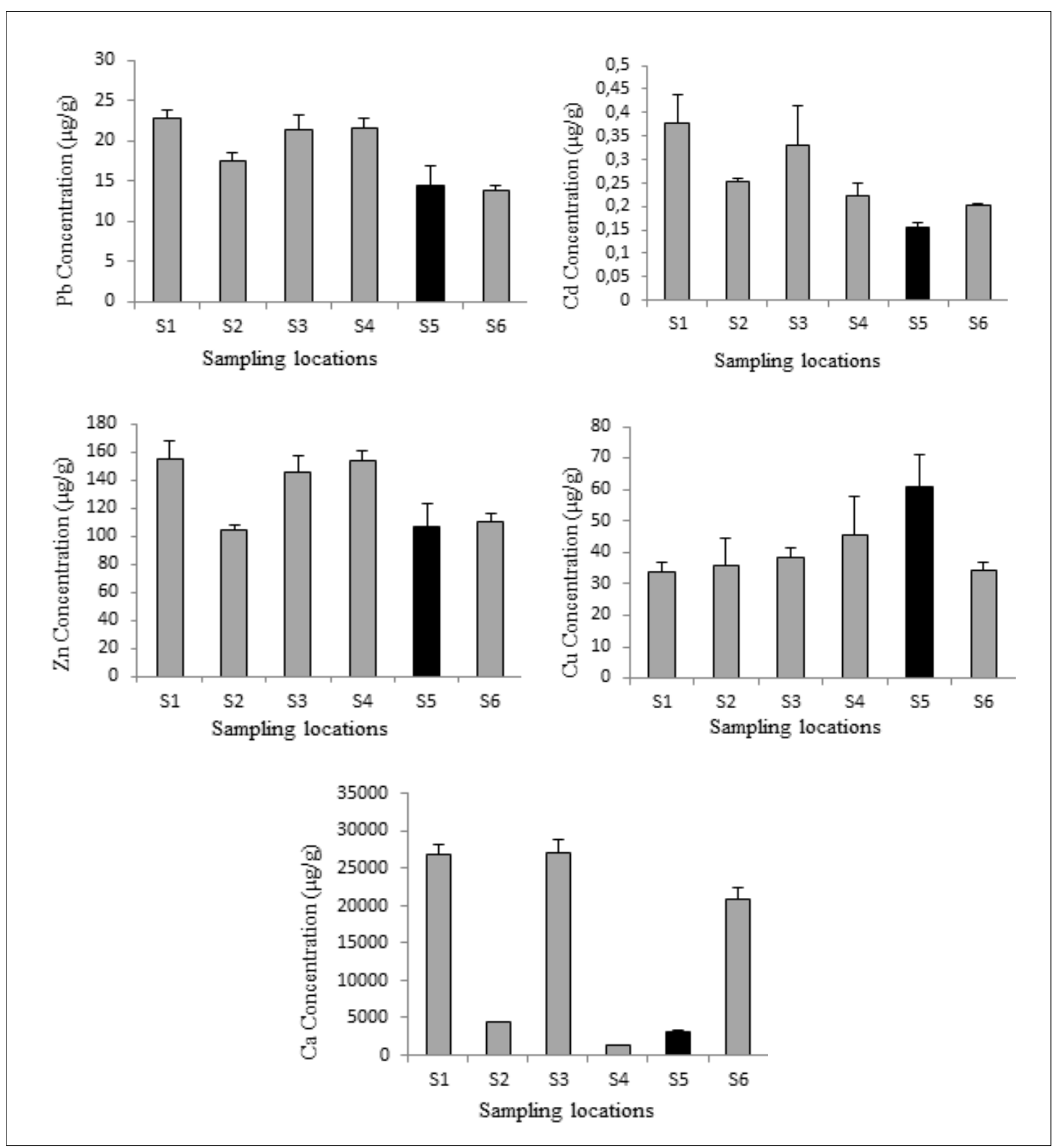

Figure 3. Concentrations (Mean $\pm S D$ ) of Lead (Pb), Cadmium (Cd), Zinc (Zn), Copper $(\mathrm{Cu})$ and Calcium $(\mathrm{Ca})$ in soils of the six sampling stations in Al Haouz plain. (S5: Reference station). Maximum permissible limits suggested by the WHO (100 $\mu \mathrm{g} / \mathrm{g}$ for $\mathrm{Pb}, 3 \mu \mathrm{g} / \mathrm{g}$ for $\mathrm{Cd}$, $300 \mu \mathrm{g} / \mathrm{g}$ for $\mathrm{Zn}$ and $100 \mu \mathrm{g} / \mathrm{g}$ for Cu) (Focus et al., 2021)

\section{Trace element concentration in Otala spp. tissues}

The contents of $\mathrm{Pb}, \mathrm{Cd}, \mathrm{Zn}, \mathrm{Cu}$ and $\mathrm{Ca}$ were evaluated in the feet, viscera and shells of Otala spp. snails collected from the six sampling stations using Principal Components Analysis (PCA) (Fig. 4). The first (69.3\%) and second principle $(21.2 \%)$ components (PC) together explained $90.45 \%$ of the total variation. Dimension 1 (Fig. 4A, B, D) opposes snail parts such as S3-F, S4-F and S6-V (on the right of the 
graph, characterized by a strongly positive coordinate on the axis) to snail parts such as S6-Sh, S3-Sh, S5- Sh, S4-Sh, S2-Sh and S1-Sh (on the left of the graph, characterized by a strongly negative coordinate on the axis).

Table 2. Trace element concentrations ( $\mu \mathrm{g} / \mathrm{g}$, dry weight) in different Otala spp. snail tissues from the six sampling stations (S1-S6) and the control snails (C). F: foot, V: viscera, Sh: shell

\begin{tabular}{|c|c|c|c|c|c|c|c|}
\hline Station & Sample & $\mathbf{P b}$ & Cd & $\mathbf{Z n}$ & $\mathbf{C u}$ & $\mathbf{F e}$ & $\mathbf{C a}$ \\
\hline \multirow{3}{*}{ S1 } & $\mathrm{F}$ & $0.63 \pm 0.06$ & $1.70 \pm 0.11$ & $74.36 \pm 7.85$ & $190.83 \pm 7.90$ & $69.23 \pm 6.93$ & $1750.00 \pm 250.00$ \\
\hline & V & $5.96 \pm 0.34$ & $7.30 \pm 0.60$ & $178.11 \pm 6.90$ & $87.92 \pm 2.66$ & $246.73 \pm 16.03$ & $8437.50 \pm 937.50$ \\
\hline & $\mathrm{Sh}$ & $0.05 \pm 0.00$ & $0.03 \pm 0.00$ & $0.12 \pm 0.01$ & $1.47 \pm 0.04$ & $490.37 \pm 12.91$ & $431818.18 \pm 26515.15$ \\
\hline \multirow{3}{*}{ S2 } & $\mathrm{F}$ & $0.59 \pm 0.02$ & $2.04 \pm 0.68$ & $123.91 \pm 6.54$ & $233.60 \pm 12.33$ & $107.71 \pm 5.30$ & $1250.00 \pm 433.01$ \\
\hline & V & $1.98 \pm 0.11$ & $7.42 \pm 1.02$ & $142.12 \pm 16.39$ & $131.59 \pm 12.05$ & $164.01 \pm 12.14$ & $2750.00 \pm 0.00$ \\
\hline & $\mathrm{Sh}$ & $0.04 \pm 0.01$ & $0.21 \pm 0.00$ & $0.06 \pm 0.00$ & $5.16 \pm 0.24$ & $489.24 \pm 10.27$ & $420454.55 \pm 0.00$ \\
\hline \multirow{3}{*}{ S3 } & $\mathrm{F}$ & $0.42 \pm 0.04$ & $2.69 \pm 0.38$ & $121.00 \pm 7.08$ & $359.97 \pm 24.23$ & $175.47 \pm 4.85$ & $3000.00 \pm 0.00$ \\
\hline & V & $0.97 \pm 0.02$ & $12.74 \pm 1.94$ & $186.47 \pm 13.78$ & $192.90 \pm 15.16$ & $182.36 \pm 12.30$ & $3000.00 \pm 250.00$ \\
\hline & Sh & $0.03 \pm 0.01$ & $0.05 \pm 0.01$ & $0.25 \pm 0.04$ & $3.35 \pm 0.05$ & $496.00 \pm 21.87$ & $409090.91 \pm 10021.79$ \\
\hline \multirow{3}{*}{ S4 } & $\mathrm{F}$ & $0.57 \pm 0.03$ & $2.17 \pm 0.09$ & $118.16 \pm 17.22$ & $285.02 \pm 18.86$ & $152.90 \pm 15.58$ & $2750.00 \pm 250.00$ \\
\hline & V & $2.08 \pm 0.31$ & $6.32 \pm 1.08$ & $245.41 \pm 11.02$ & $186.15 \pm 6.62$ & $234.13 \pm 29.58$ & $2750.00 \pm 250.00$ \\
\hline & $\mathrm{Sh}$ & $0.03 \pm 0.00$ & $0.05 \pm 0.00$ & $0.10 \pm 0.00$ & $1.87 \pm 0.52$ & $497.68 \pm 13.55$ & $382575.76 \pm 15151.52$ \\
\hline \multirow{3}{*}{ S5 } & $\mathrm{F}$ & $0.47 \pm 0.02$ & $1.39 \pm 0.06$ & $72.56 \pm 9.47$ & $389.74 \pm 14.23$ & $100.09 \pm 16.43$ & $5937.50 \pm 826.80$ \\
\hline & V & $2.10 \pm 0.23$ & $6.95 \pm 2.43$ & $160.64 \pm 21.31$ & $181.89 \pm 11.33$ & $169.46 \pm 20.21$ & $3000.00 \pm 250.00$ \\
\hline & $\mathrm{Sh}$ & $0.02 \pm 0.00$ & $0.00 \pm 0.00$ & $0.08 \pm 0.01$ & $0.43 \pm 0.04$ & $471.55 \pm 18.24$ & $416666.67 \pm 29584.28$ \\
\hline \multirow{3}{*}{ S6 } & $\mathrm{F}$ & $0.84 \pm 0.08$ & $3.12 \pm 0.88$ & $144.21 \pm 21.83$ & $256.12 \pm 28.44$ & $230.09 \pm 17.16$ & $4375.00 \pm 312.50$ \\
\hline & $\mathrm{V}$ & $2.18 \pm 0.32$ & $8.44 \pm 1.26$ & $167.10 \pm 14.45$ & $225.55 \pm 24.65$ & $192.92 \pm 8.83$ & $3000.00 \pm 0.00$ \\
\hline & $\mathrm{Sh}$ & $0.05 \pm 0.00$ & $0.15 \pm 0.02$ & $0.15 \pm 0.04$ & $5.61 \pm 0.86$ & $470.82 \pm 16.04$ & $401515.15 \pm 24838.78$ \\
\hline \multirow{3}{*}{ Control } & $\mathrm{F}$ & $0.11 \pm 0.01$ & $0.15 \pm 0.04$ & $41.99 \pm 5.87$ & $79.91 \pm 6.99$ & $578.20 \pm 14.81$ & $22666.67 \pm 1222.02$ \\
\hline & $\mathrm{V}$ & $0.16 \pm 0.04$ & $0.21 \pm 0.07$ & $200.73 \pm 11.62$ & $122.30 \pm 17.08$ & $144.81 \pm 9.87$ & $17500.00 \pm 0.00$ \\
\hline & Sh & $0.03 \pm 0.01$ & $0.00 \pm 0.00$ & $0.91 \pm 0.23$ & $2.02 \pm 0.66$ & $486.05 \pm 9.44$ & $378787.88 \pm 13121.60$ \\
\hline
\end{tabular}

The classification carried out on individuals reveals 3 classes:

Class 1 is made up of individuals such as S1-Sh, S2-Sh, S3-Sh, S4-Sh, S5-Sh and S6-Sh. This group is characterized by:

- High values for the variable $\mathrm{Ca}$

- Low values for the variables $\mathrm{Zn}, \mathrm{Cu}, \mathrm{Cd}$ and $\mathrm{Pb}$ (from the most extreme to the least extreme)

Class 2 is made up of individuals such as S3-F, S4-F and S5-F. This group is characterized by:

- High values for the $\mathrm{Cu}$ variable

- Low values for the variable $\mathrm{Ca}$

Class 3 is made up of individuals such as $\mathrm{S} 1-\mathrm{V}, \mathrm{S} 3-\mathrm{V}, \mathrm{S} 4-\mathrm{V}$ and $\mathrm{S} 6-\mathrm{V}$. This group is characterized by:

- High values for the variables $\mathrm{Cd}, \mathrm{Zn}$ and $\mathrm{Pb}$ (from the most extreme to the least extreme)

- Low values for the variable $\mathrm{Ca}$

The distribution according to sampling stations (Fig. 4C) showed that they had no apparent impact on metals' concentrations. 

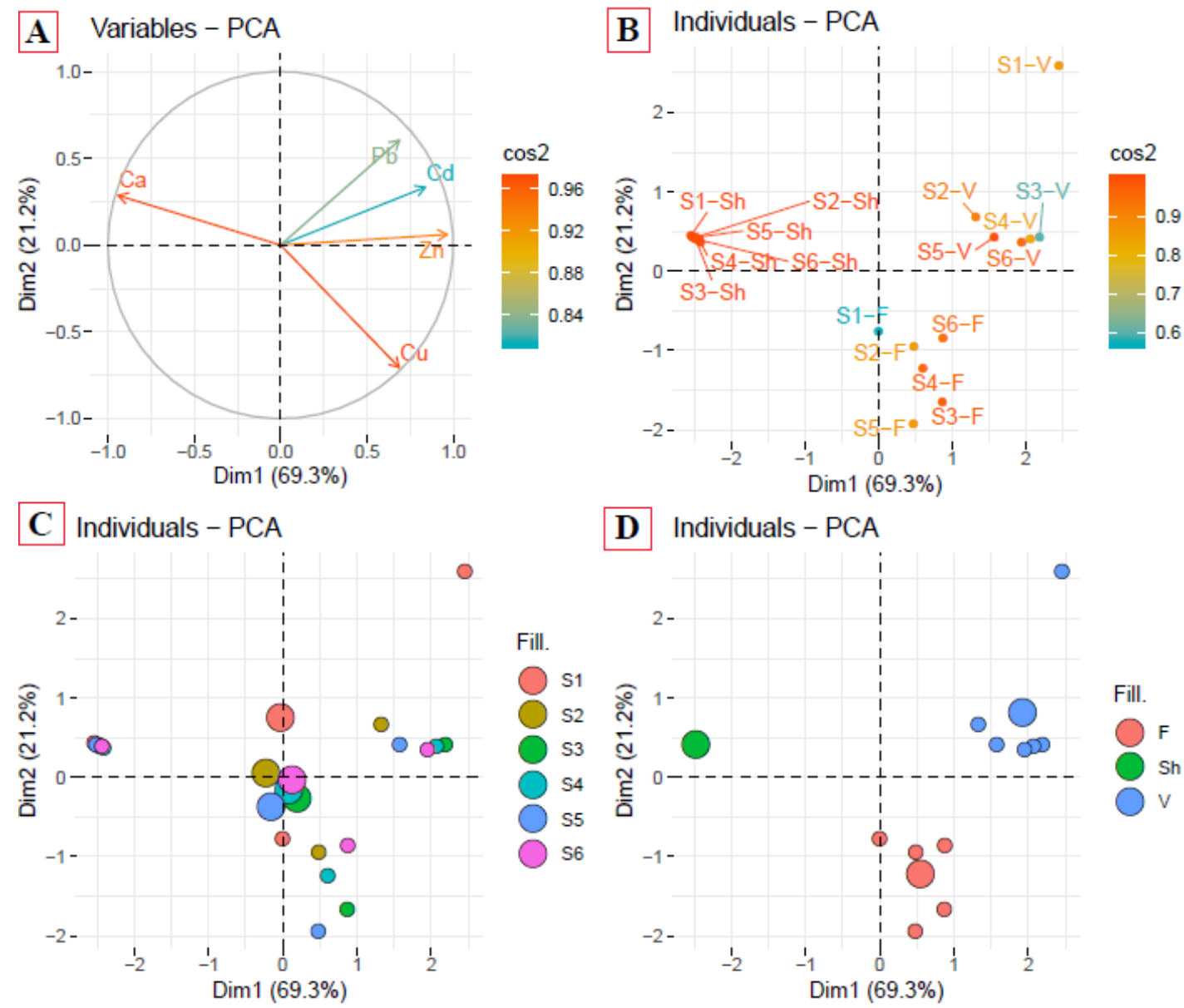

Figure 4. PCA analysis of trace element concentrations in Otala spp. snail tissues (A: Metal distribution, $B$ and $D$ : tissue distribution, $C$ : station distribution)

\section{Bioaccumulation factor}

In order to compare and to assess the metal levels in snail tissues and in associated soil, the Bioaccumulation Factor was calculated (Fig. 5) (Adediran et al., 2003). This can be represented in Equation 1:

$$
B A F=\frac{\text { Concentration of the element in tissue }}{\text { Concentration of the same element in soil }}
$$

We considered that the element bioaccumulation is low when $\mathrm{BAF}<1$, medium when $1<\mathrm{BAF}<5$ and high when $\mathrm{BAF}>5$.

The calculated $\mathrm{BAF}_{\mathrm{F}}, \mathrm{BAF}_{\mathrm{V}}$ and $\mathrm{BAF}_{\mathrm{Sh}}$ values were very low for $\mathrm{Pb}$ in the six sampling stations with an average ranging between 0.019-0.061, 0.04-0.26 and 0.0010.003 respectively. The BAF values below 1 indicate that $\mathrm{Pb}$ do not bioaccumulate in snail tissues.

Cd showed high bioaccumulation factor values for foot and viscera and low values for shell. These values ranged between 4.49-15.44 for foot, 19.26-44.35 for viscera and 0.014-0.84 for shell.

Otherwise, BAF values of the three essential elements $\mathrm{Zn}, \mathrm{Cu}$ and $\mathrm{Ca}$ show variable results depending on the snail part as well as the sampling station. Generally, shells 
registered the lower values for $\mathrm{Zn}$ and $\mathrm{Cu}\left(\mathrm{BAF}_{\mathrm{sh}}<1\right)$ but the highest for $\mathrm{Ca}$ $\left(15.15<\mathrm{BAF}_{\text {sh }}<272.05\right)$.

Foot part demonstrated better efficiency in accumulating $\mathrm{Cu}$ with a $\mathrm{BAF}_{\mathrm{Cu}}$ up to 9.34 while viscera presented a high $\mathrm{BAF}_{\mathrm{Cu}}$ only in Tahannaout and Laâtamna $\left(\mathrm{BAF}_{\mathrm{Cu}}=5\right.$ and $\mathrm{BAF}_{\mathrm{Cu}}=6.6$ ).

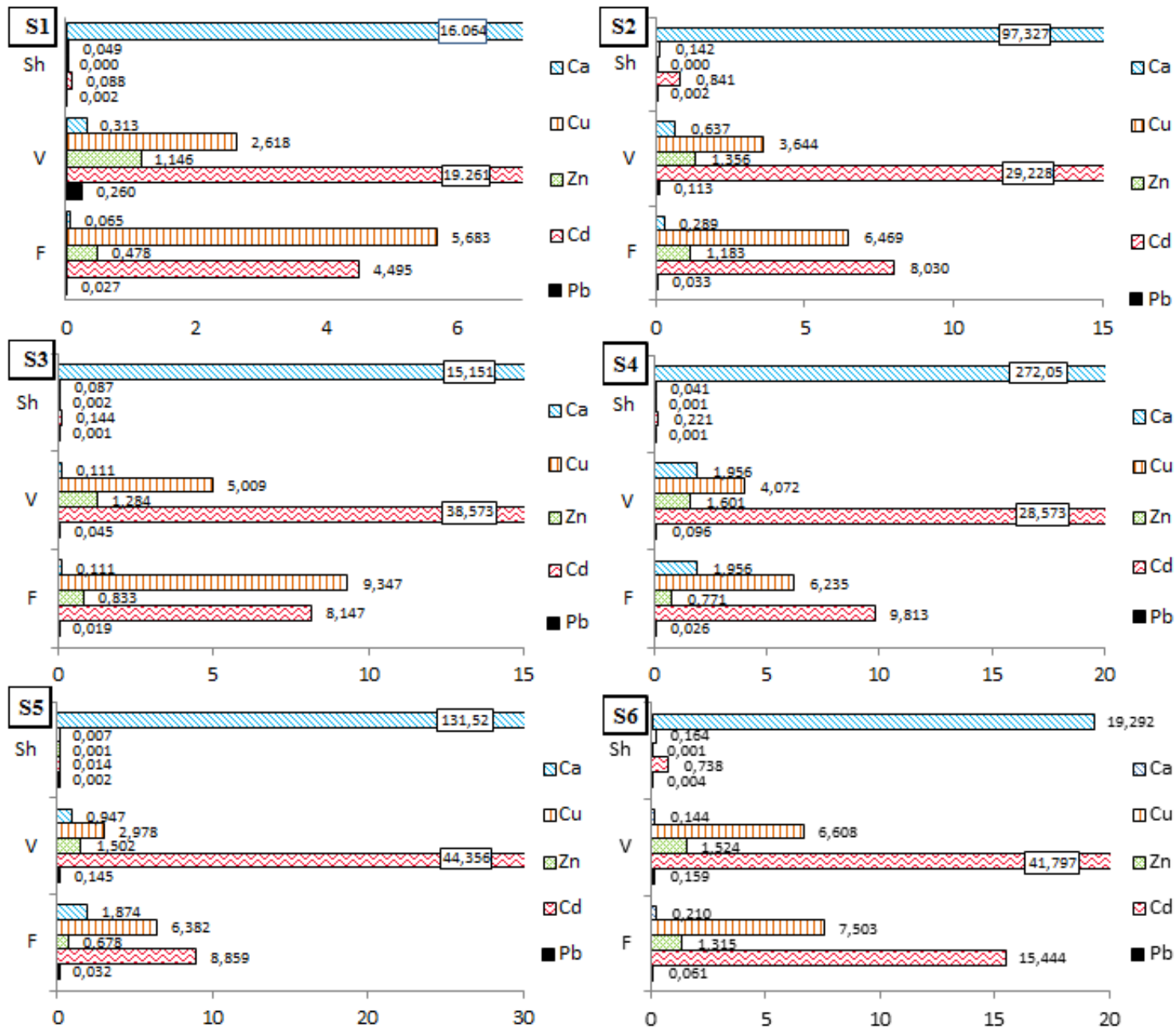

Figure 5. Bioaccumulation factors (BAF) of $\mathrm{Pb}, \mathrm{Cd}, \mathrm{Zn}, \mathrm{Cu}$ and $\mathrm{Ca}$ in different parts of Otala spp. snails compared to soil of the six sampling stations

\section{Discussion}

Our study was carried out in five farms with agricultural activities, while the reference station was an open area without any agricultural activity. Farmers use fertilizers and pesticides to improve their production and control crop pests and weeds. However, these products may contain trace elements and their random usage can modify the characteristics of soil and even promote the bioavailability of some trace elements. Hence, because of the lack of control and awareness on the correct use of these products, they can turn from beneficial elements into a source of pollution for the abiotic compartments as well as for terrestrial organisms including snails.

Otala spp. snails are the most commonly widespread and the most consumed species in Marrakech. Besides being a popular local dish, large amounts of these species, 
generally coming from unregulated collecting in the wild and farms, are intended for international consumption and exported from Morocco annually. Despite their national and international popularity, the quality of $O$. lactea and $O$. punctata snails, the trace element contents and the accumulation efficiency have never been studied before. The objective of this study is to fill this gap and to raise public awareness about food quality, especially for snail meat consumers, and then to push authorities to regularize the collection of these gastropods in order to avoid any human health risks and to protect a lot of endangered snail species.

The first results of this study showed significant differences between the analyzed soil samples that were possibly caused by anthropogenic activities especially for $\mathrm{Cu}$ which is a principal constituent of fertilizers. That is a rational reason since we are investigating in lands with agricultural activities. Otherwise, all the terrestrial metal concentrations of this study were below the maximum permissible limits suggested by the World Health Organization $(100 \mu \mathrm{g} / \mathrm{g}$ for Pb, $3 \mu \mathrm{g} / \mathrm{g}$ for $\mathrm{Cd}, 300 \mu \mathrm{g} / \mathrm{g}$ for $\mathrm{Zn}$ and $100 \mu \mathrm{g} / \mathrm{g}$ for $\mathrm{Cu}$ ) (Focus et al., 2021). They are also lower than those of Notten et al. (2005) and Madejón et al. (2013) but higher than those of Khalil (2013) except for Cd.

Moreover, the measurement of metallic element concentrations in land snails has been widely used to monitor the environmental levels of these elements in soils, specifically thanks to their ability of accumulation in high concentrations (Madejón et al., 2013; De Roma, 2017). It has been revealed in this study that all the studied trace elements were detected in the sampled snails. This result confirms the ability of terrestrial snails, including Otala spp., to assimilate and accumulate trace elements as reported by several previous investigations (Fritsch et al., 2011; Magdalena et al., 2013; Larba and Soltani, 2014; Esposito et al., 2016).

Compared to other researches, Otala spp. snails in this study accumulated more levels of $\mathrm{Pb}, \mathrm{Cd}, \mathrm{Zn}$ and $\mathrm{Cu}$ than Theba pisana land snail (Madejón et al., 2013) and Lanistes carinatus freshwater snail. (Abdel Gawad, 2018). However, high values up to $33 \mu \mathrm{g} / \mathrm{g}$ for $\mathrm{Cd}$, up to $313 \mu \mathrm{g} / \mathrm{g}$ for $\mathrm{Pb}$ and up to $2422 \mu \mathrm{g} / \mathrm{g}$ for $\mathrm{Zn}$ have been recorded in Cantareus aspersus garden snail (Pauget et al., 2015).

These elements accumulate by ingestion, as snails not only feed on plants which in turn may contain concentrations of trace elements, but they also ingest significant amounts of soil. On the other hand, the respiratory or dermal tract may also be a significant source of accumulation. Firstly, because land snails have a vascularized lung with a big pneumostome and a skin covered with mucus which can promote several interactions with their biotope. Therefore, snails can sometimes concentrate high levels and become biological and chemical contaminant vectors, especially in the case of snail predators (Wijnhoven et al., 2007; Scaffardi and Giordana, 2007).

The levels of accumulated $\mathrm{Cd}$ were higher than those of $\mathrm{Pb}$. Concordant and similar results were observed in experiments on other land snails which found that they are macroconcentrators for $\mathrm{Cd}$ and microconcentrators for $\mathrm{Pb}$. These elements are known to be accumulated in organs with high metabolic activity such us hepatopancreas and digestive gland (Manzl et al., 2004; Nica et al., 2014; Mleiki et al., 2016; Baroudi et al., 2020).

Studying trace element levels in Otala spp. snail tissues seems necessary to understand the bioaccumulation and the transfer process from the soil to the higher trophic levels of the food chain, especially those of snails' predators and humans. By doing this, we can get an idea about the levels of bioaccumulated trace elements and then to evaluate the risk of these cumulative metals on the other organisms' health. 
In short, the PCA analysis revealed that the levels of most metallic trace elements were higher in the viscera than the foot, while shell accumulates only low concentrations. On the other hand, it was noteworthy that shells accumulate higher levels of Calcium than the other snail parts. Large amounts of Calcium are generally used by snails and other shelled animals to form their shells hence its elevated values in these findings (Ebenso, 2003). These results corroborate with several studies on snails (Deng et al., 2008; Bao et al., 2018).

It has been noticed also that $\mathrm{Cu}$ contents were higher in the foot part. In fact, this is an obvious result since Copper is an essential constituent of the oxygen-carrying protein, haemocyanin. (Otitoloju et al., 2009). Viscera accumulate more $\mathrm{Cd}, \mathrm{Zn}$ and $\mathrm{Pb}$ than the other parts. Earlier studies have shown that the detoxification process of bioavailable non-essential elements and essential elements, assumed in excess, occurs in digestive gland and their bioaccumulation is due to the compartmentalization in intercellular granules or vesicles in the digestive gland or other tissues (Regoli et al., 2006; Boshoff et al., 2013).

These concentrations are usually influenced by diverse parameters such as snail age, physico-chemical soil properties, soil and air moisture, vegetation and concentrations of metals in soil. They can be very variable even in snails collected from the same area (Bargagli, 1998). Other studies confirm these findings and demonstrate that the metal concentration and soil characteristics explain $40-67 \%$ of the accumulation of metals in snails. Furthermore, pH, Cation-exchange capacity (CEC) and oxides (Fe and $\mathrm{Al}$ ) modulate the bioavailability of $\mathrm{Cd}, \mathrm{Pb}$ and $\mathrm{Zn}$ for snails (Pauget, 2012).

$\mathrm{Pb}$ accumulated in invertebrates is considered as a non-essential element (Rainbow, 2007; Lanno et al., 2019; Kumar et al., 2020). Unlike Pb, Cd, which has no important role for biological needs of the organism body (Kubier et al., 2019), showed high bioaccumulation factor values for foot and viscera and low values for shell. Similar results have been obtained by other authors in Helix vladika and Helix secernenda of Montenegro ( $\mathrm{BAF} P \mathrm{~Pb}<1$ and $1.2<\mathrm{BAF}_{\mathrm{Cd}}<25.2$ ) (Vukašinovic-Pešic et al., 2020) while Mohammadein et al. (2013) found that both $\mathrm{BAF}_{\mathrm{Pb}}$ and $\mathrm{BAF}_{\mathrm{Cd}}$ are below 1 in tissues of Eobania vermiculata of Taif city. As found by other studies, our findings confirm that Otala lactea and Otala punctata snails are macrconcentrators for Cd, especially in their flesh, because they concentrate higher levels than their environment.

Generally, shells accumulated the lower levels for $\mathrm{Zn}$ and $\mathrm{Cu}$ but the highest for $\mathrm{Ca}$. Feet demonstrated better efficiency in accumulating Cu. Dallinger and Wiesser (1984) showed that there was no preference for any organ in the distribution of $\mathrm{Cu}$ in Helix pomatia snails. In addition, earlier studies corroborates that gastropods usually showed much higher concentrations of $\mathrm{Zn}$ in their soft tissues than in their shells (De Wolf et al., 2001).

All these findings validate the hypothesis that $O$. lactea and O. punctata, like the most previously investigated species, are promising trace element bioindicators especially for $\mathrm{Cd}, \mathrm{Cu}, \mathrm{Ca}$ and $\mathrm{Zn}$.

On the other hand, the toxic element contents in the edible part (foot) ranged between 0.42 and $0.84 \mu \mathrm{g} / \mathrm{g}$ for $\mathrm{Pb}$ and between 1.39 and $3.12 \mu \mathrm{g} / \mathrm{g}$ for $\mathrm{Cd}$. We can observe that $\mathrm{Pb}$ contents are below the permissible levels $(1.5 \mu \mathrm{g} / \mathrm{g}$ (dry weight)) established by the national and EU regulations (EU commission regulation No 1881/2006 of 19 December, 2006) in all the sampling stations. Contrariwise, Cd contents are above the allowable limits in mollusk meat $(1.0 \mu \mathrm{g} / \mathrm{g}$ (dry weight)). This can threaten the safety of snail meat consumers especially in the long term, hence the exigency to establish and impose collection regulations in lands without any suspected metallic contaminations. 


\section{Conclusion}

The edible Otala lactea and Otala punctata snails of Marrakech can be used as sentinel species to evaluate terrestrial pollution by trace metals. The results of this investigation showed large variability in concentrations of studied trace elements depending on the snail tissues and metal bioavailability. These snail species also have the quality of macroconcentration for $\mathrm{Cd}$ and microconcentration for $\mathrm{Pb}$ with levels that reached $15.48 \mu \mathrm{g} / \mathrm{g}(\mathrm{Cd})$ and $6.63 \mu \mathrm{g} / \mathrm{g}(\mathrm{Pb})$. Ca appears to be the most accumulated element in the shell $(382.58 * 103 \mu \mathrm{g} / \mathrm{g}<\mathrm{Ca}<431.09 * 103 \mu \mathrm{g} / \mathrm{g})$ while $\mathrm{Cu}$ is the most accumulated in the foot $(190.83 \mu \mathrm{g} / \mathrm{g}<\mathrm{Cu}<389.74 \mu \mathrm{g} / \mathrm{g})$. Viscera had a tendency to accumulate more toxic metals $(0.97 \mu \mathrm{g} / \mathrm{g}<\mathrm{Pb}<5.96 \mu \mathrm{g} / \mathrm{g}$ and $6.32<\mathrm{Cd}<12.74 \mu \mathrm{g} / \mathrm{g})$ and $\mathrm{Zn}(142.1 \mu \mathrm{g} / \mathrm{g}<\mathrm{Zn}<245.41 \mu \mathrm{g} / \mathrm{g})$ than the other parts. The detected concentrations may pose a potential health risk to consumers as well as to snail predators hence the necessity of continuous monitoring of the snail products intended for consumption. Moreover, organic farming must also be encouraged to preserve these endangered species and improve the quality of the product marketed nationally and internationally. In conclusion, the dataset confirmed that Otala spp. snails represent a potential candidate to monitor soil contamination in terrestrial ecosystems. However, no information exists in the literature concerning their limitations as ecological indicators, their usage in atmospheric monitoring, and the toxic effects of trace elements for these snails. For that several studies and further analysis must be conducted in the future to answer all the previous questions.

Acknowledgements. We would greatly thank Yannick François for the rendered help during the sample analysis and Fatima Zahra Guennoun for the species identification.

\section{REFERENCES}

[1] Abdel Gawad, S. (2018): Concentrations of heavy metals in water, sediment and mollusk gastropod, Lanistes carinatus from Lake Manzala, Egypt. - The Egyptian Journal of Aquatic Research 44(2): 77-82.

[2] Adediran, J. A., De Baets, N., Mnkeni, P. N. S., Kienkens, L., Muyima, N. Y. O., Thys, A. (2003): Organic waste materials for soil fertility improvement in the border region of the eastern cape. South Africa. - Biol. Agric. Hortic. 20: 283-300.

[3] American Psychological Association (APA). (2018): Guidelines for Ethical Conduct in the Care and Use of Nonhuman Animals in Research. - Committee on Animal Research and Ethics (CARE), Washington, DC.

[4] Anim, A. K., Ackah, M., Fianko, J. R., Kpattah, L., Osei, J., SerforArmah, Y., Gyamfi, E. T. (2011): Trace elements composition of Achatina achatina samples from the Madina Market in Accra, Ghana. - Research Journal of Environmental and Earth Sciences 3: 564570 .

[5] Bao, S., Huang, J., Liu, X., Tang, W., Fang, T. (2018): Tissue distribution of Ag and oxidative stress responses in the freshwater snail Bellamya aeruginosa exposed to sediment-associated Ag nanoparticles. Sci Total Environ. 644: 736-746.

[6] Bargagli, R. (1998): Trace Elements in Terrestrial Plants: An Ecophysiological Approach to Biomonitoring and Biorecovery. - Springer-Verlag, Berlin.

[7] Baroudi, F., Al Alam, J., Fajloun, Z., Millet, M. (2020): Snail as sentinel organism for monitoring the environmental pollution; a review. - Ecological Indicators 113: 106240.

[8] Boshoff, M., Jordaens, K., Backeljau, T., Lettens, S., Tack, F., Vandecasteele, B., De Jonge, M., Bervoets, L. (2013): Organ- and species-specific accumulation of metals in 
two land snail species (Gastropoda, Pulmonata). - Science of The Total Environment 449: 470-481.

[9] Caracciolo, A. B., Terenzi, V. (2021): Rhizosphere microbial communities and heavy metals. - Microorganisms 9(7): 1462.

[10] Chrzan, A. (2017): The impact of heavy metals on the soil fauna of selected habitats in Niepołomice forest. - Polish J. Soil Sci. 2: 291-300.

[11] Dallinger, R., Wieser, W. (1984): Patterns of accumulation, distribution and liberation of $\mathrm{Zn}, \mathrm{Cu}, \mathrm{Cd}$, and $\mathrm{Pb}$ in different organs of the land snail Helix pomatia L. Comp. Biochem. - Phys. C 79: 117-124.

[12] De Roma, A., Neola, B., Serpe, F. P., Sansone, D., Picazio, G., Cerino, P. M. (2017): Land snails (Helix aspersa) as Bioindicators of Trace Element Contamination in Campania (Italy). - OALib 4(2): 1-12.

[13] De Wolf, H., Ulomi, S. A., Backeljau, T., Pratap, H. B., Blust, R. (2001): Heavy metal levels in the sediments of four Dar es Salaam mangroves accumulation in, and effect on the morphology of the periwinkle, Littoraria scabra (Mollusca: Gastropoda). Environment International 26: 243-249.

[14] Deng, P. Y., Shu, W. S., Lan, C. Y., Liu, W. (2008): Metal contamination in the sediment, pondweed, and snails of a stream receiving effluent from a lead/zinc mine in southern China. - Bull Environ Contam Toxicol. 81: 69-74.

[15] Ebenso, I. E. (2003): Dietary calcium supplement for edible tropical land snails Archachatina marginata in Niger Delta, Nigeria. - Livestock Research for Rural Development 15: 1-5.

[16] Ejidike, I. P., Onianwa, P. C. (2015): Assessment of trace metals concentration in tree barks as indicator of atmospheric pollution within Ibadan City, South-West, Nigeria. - J. Anal. Methods Chem. 243601.

[17] Esposito, M., Serpe, F. P., Neola, B., Sansone, D., Fiorito, F., Cerino, P. (2016): Use of Snails (Helix aspersa) as Sentinels to Evaluate Environmental Contamination by Polycyclic Aromatic Hydrocarbons and Trace Element. $-70^{\text {th }}$ Convegno SISVET ts Conference, Palermo, Italy.

[18] Focus, E., Rwiza, M. J., Mohammed, N. K., Banzi, F. P. (2021): Health risk assessment of trace elements in soil for people living and working in a mining area. - Journal of Environmental and Public Health. DOI: 10.1155/2021/9976048.

[19] Fritsch, C., Cœurdassier, M., Gimbert, F., Crini, N., Scheifler, R., de Vaufleury, A. (2011): Investigations of responses to metal pollution in land snail populations (Cantareus aspersus and Cepaea nemoralis) from a smelter-impacted area. - Ecotoxicology 20: 73959.

[20] Ghemari, C., Waterlot, C., Ayari, A., Leclercq, J., Douay, F., Nasri-Ammar, K. (2017): Assessment of heavy metals in soil and terrestrial isopod Porcellio laevis in Tunsian industrialized areas. - Environ Earth 76: 623.

[21] Gomot De Vaufeury, A., Pihan, F. (2000): Growing snails used as sentinels to evaluate terrestrial environment contamination by trace elements. - Chemosphere 40: 275-284.

[22] Gomot, A. (1998): Biochemical composition of Helix snails: influence of genetic and physiopathological factors. - Journal of Mollusca. Studies 64: 173-181.

[23] Herbert, D. G. (2010): The Introduced Terrestrial Mollusca of South Africa. - SANBI Biodiversity Series 15. South African National Biodiversity Institute, Pretoria.

[24] High Commission for Planning, Regional Planning Directorate for the Marrakech - Safi Region (2018): Regional Monograph. - Marrakech, Safi Region.

[25] Indexbox (2019): World - Snails (Except Sea Snails) - Market Analysis, Forecast, Size, Trends and Insights. - Indexbox.

[26] Jahan, S., Strezov, V. (2019): Assessment of trace elements pollution in the sea ports of New South Wales (NSW), Australia using oysters as bioindicators. - Sci Rep. 9: 1416. 
[27] Khalil, A. M. (2013): The effects of soil heavy metals pollution and seasonal variations on gametogenesis and energy reserves of the land snail Eobania vermiculata. - J Biol Earth Sci. 3(2): 206-213.

[28] Kubier, A., Wilkin, R. T., Pichler, T. (2019): Cadmium in soils and groundwater: a review. - Applied Geochemistry 108: 104388.

[29] Kumar, A., Cabral-Pinto, M. M. S., Chaturvedi, A. K., Shabnam, A. A., Subrahmanyam, G., Mondal, R., Gupta, D. K., Malyan, S. K., Kumar, S., Khan, A. S., Yadav, K. K. (2020): Lead toxicity: health hazards, influence on food chain, and sustainable remediation approaches. - International Journal of Environmental Research and Public Health 17(7): 2179.

[30] Lanno, R. P., Oorts, K., Smolders, E., Albanese, K., Chowdhurye, M. J. (2019): Effects of soil properties on the toxicity and bioaccumulation of lead in soil invertebrates. Environmental Toxicology and Chemistry 38: 1486-1494.

[31] Larba, R., Soltani, N. (2014): Use of the land snail Helix aspersa for monitoring heavy metal soil contamination in Northeast Algeria. - Environmental Monitoring and Assessment 186: 4987-4995.

[32] Luczynska, J., Paszczyk, B., Luczynski, M. J. (2018): Fish as a bioindicator of heavy metals pollution in aquatic ecosystem of Pluszne Lake, Poland, and risk assessment for consumer's health. - Ecotoxicol Environ Saf. 153: 60-67.

[33] Madejón, P., Arrébola, J., Madejón, E., Burgos, P., López-Garrido, R., Cárcaba, A., Cabrera, F., Murillo, J. M. (2013): The snail Theba pisana as an indicator of soil contamination by trace elements: potential exposure for animals and humans. - J. Sci. Food Agric. 93: 2259-2266.

[34] Magdalena, B., Kurt, J., Thierry, B., Suzanna, L., Filip, T., Bart, V., Maarten, D. J., Lieven, B. (2013): Organ- and species-specific accumulation of metals in two land snail species (Gastropoda, Pulmonata). - Science of the Total Environment 449: 470-481.

[35] Manev, I., Kirov, V., Neshovska, H. (2020): Heavy metals accumulation in black sea ecosystems: seawater, sediment, algae, benthic organisms. - Tradition And Modernity in Veterinary Medicine 5: 88-99.

[36] Manzl, C., Krumschnabel, G., Schwarzbaum, P. J., Dallinger, R. (2004): Acute toxicity of cadmium and copper in hepatopancreas cells from the Roman snail (Helix pomatia). Comparative Biochemistry and Physiology Part C: Toxicology \& Pharmacology 138: 4552.

[37] Minodora, M. (2017): Soil invertebrates - a useful tool in biomonitoring of heavy metal pollution. A Review. - Studia Universitatis "Vasile Goldiş", Seria Ştiinţele Vieţii 27(4): 247-258.

[38] Mleiki, A., Irizar, A., Zaldibar, B., El Menif, N. T., Marigómez, I. (2016): Bioaccumulation and tissue distribution of $\mathrm{Pb}$ and $\mathrm{Cd}$ and growth effects in the green garden snail, Cantareus apertus (Born, 1778), after dietary exposure to the metals alone and in combination. - Sci Tot Environ. 547: 148-156.

[39] Mohammadein, A., El-Shenawy, N. S., Al-Fahmie, Z. H. H. (2013): Bioaccumulation and histopathological changes of the digestive gland of the land snail Eobania vermiculata (Mollusca: Gastropoda), as biomarkers of terrestrial heavy metal pollution in Taif city. Ital. J. Zool. 80: 345-357.

[40] Müller, O. F. (1774): Vermium terrestrium et fluviatilium, seu animalium infusorium, Helminthicorum, et testaceorum, non marinorum, succincta historia. V 2: I-XXXVI, 1214. - Heineck et Faber, Havnia et Lipsia.

[41] Munees, A. (2019): Remediation of metalliferous soils through the heavy metal resistant plant growth promoting bacteria: paradigms and prospects. - Arabian Journal of Chemistry 12(7): 1365-1377.

[42] Nica, D. V., Bordean, D-M., Hărmănescu, M., Buram, G. I. (2014): Interactions among heavy metals $(\mathrm{Cu}, \mathrm{Cd}, \mathrm{Zn}, \mathrm{Pb})$ and metallic macroelements $(\mathrm{K}, \mathrm{Ca}, \mathrm{Na}, \mathrm{Mg})$ in Roman snail (Helix pomatia) soft tissues. - Acta Metallomica - MEEMB 11: 65-71. 
[43] Notten, M., Oosthoek, A., Rozema, J., Aerts, R. (2005): Heavy metal concentrations in a soil-plant-snail food chain along a terrestrial soil pollution gradient. - Environ. Pollut. 138: 178-190.

[44] Orcid, O. K., Orcid, O. S. (2019): Heavy metals in the dandelion and apple tree pollen from the different terrestrial ecosystems of the Carpathian region. - Acta Sci. Pol. Zootechnica 18(3): 15-20.

[45] Otitoloju, A. A., Ajikobi, D. O., Egonmwan, R. I. (2009): Histopathology and bioaccumulation of heavy metals $(\mathrm{Cu} \& \mathrm{~Pb})$ in the giant land snail, Archachatina marginata (Swainson). - The Open Environmental Pollution and Toxicology Journal 1: 79-88.

[46] Pankova, E. S., Kamnev, A. N., Golubeva, E. I. (2015): Features of the distribution of heavy metals in brown algae Cystoseira barbata. - International Popular Science Journal Europe-Asia. Earth Sciences 5: 25-28.

[47] Parmar, T., Rawtani, D., Agrawal, Y. (2016): Bioindicators: the natural indicator of environmental pollution. - Frontiers in Life Science 9: 1-9.

[48] Parolini, M., Sturini, M., Maraschi, F., Profumo, A., Costanzo, A., Caprioli, M., Rubolini, D., Ambrosini, R., Canova, L. (2021): Trace elements fingerprint of feathers differs between breeding and non-breeding areas in an Afro-Palearctic migratory bird, the barn swallow (Hirundo rustica). - Environ Sci Pollut Res Int. 28(13): 15828-15837.

[49] Pauget, B. (2012): Determination of the soil parameters that influence the metal bioavailability and accumulation for the snails (Cantareus aspersus). - Thesis Université de Franche-comté U.F.R. des sciences et techniques Laboratoire Chrono-Environnement (UMR CNRS/UFC 6249, Usc INRA).

[50] Pauget, B., Faure, O., Conord, C., Crini, N., De Vaufleury, A. (2015): In situ assessment of phyto and zooavailability of trace elements: a complementary approach to chemical extraction procedures. - Sci Total Environ 521-522: 400-410.

[51] Rainbow, P. S. (2007): Trace metal bioaccumulation: model, metabolic availability and toxicity. - Environment International 33(4): 576-82.

[52] Regoli, F., Gorbi, S., Fattorini, D., Tedesco, S., Notti, A., Machella, N., Bocchetti, R., Benedetti, M., Piva, F. (2006): Use of the land snail Helix aspersa as sentinel organism for monitoring ecotoxicologic effects of urban pollution: an integrated approach. Environ. Health Perspect. 114: 63-69.

[53] Robinson, D. G., Redmond, L., Hennessey, R. (1998): Importation and interstate movement of live, edible land snails: Cantareus apertus (Born), Cryptomphalus aspersus (Müller), Eobania vermiculata (Müller), Helix pomatia Linné, and Otala lactea (Müller) (Pulmonata: Helicidae). - Qualitative Pest Risk Assessment. USDA APHIS PPQ Scientific Services, Riverdale, MD.

[54] Scaffardi, E., Ru, G., Giordana, G. (2007): Accumulo di metalli pesanti in chiocciole della specie Helix pomatia L. (Pulmonata, Helicidae) destinate al consumo umano. - Il Chirone 1: 8-11.

[55] Shahid, M., Dumat, C., Khalid, S., Schreck, E., Xiong, T., Niazi, N. K. (2016): Foliar heavy metal uptake, toxicity and detoxification in plants: a comparison of foliar and root metal uptake. - Journal of Hazardous Materials, Elsevier 325: 36-58.

[56] Shotuyo, A. L., Bambgose, O., Oduntan, O. O., et al. (2016): Levels of some heavy metals in African Giant Land Snail (Archachatina marginata) in major markets in Abeokuta, South West Nigeria. - International Journal of Molecular Ecology and Conservation 6(1): 1-6.

[57] Ugbaja, R. N., Enilolobo, M. A., James, A. S., Akinhanmi, T. F., Akamo, A. J., Babayemi, D. O., Ademuyiwa, O. (2020): Bioaccumulation of heavy metals, lipid profiles, and antioxidant status of snails (Achatina achatina) around cement factory vicinities. - Toxicol. Ind. Health 36(11): 863-875.

[58] Vukašinovic-Pešic, V., Pilarczyk, B., Miller, T., Rajkowskamysliwiec, R., Podlasinska, J., Tomza-Marciniak, A., Blagojevic, N., Trubljanin, N., Zawal, A., Pešic, V. (2020): 
Toxic elements and mineral content of different tissues of endemic edible snails (Helix vladika and H. secernenda) of Montenegro. - Foods 9: 731.

[59] Wang, K., Qiao, Y., Zhang, H., Yue, S., Li, H., Ji, X., Liu, L. (2018): Bioaccumulation of heavy metals in earthworms from field contaminated soil in a subtropical area of China. Ecotoxicology and Environmental Safety 148: 876-883.

[60] Wijnhoven, S., Leuven, R., van der Velde, G., Jungheim, G., Koelemij, E., de Vries, F., Eijsackers, H., Smits, A. (2007): Heavy-metal concentrations in small mammals from a diffusely polluted floodplain: importance of species- and location specific characteristics. - Archives of Environmental Contamination and Toxicology 52: 603-613. 